\title{
MODERN ASPECTS OF EU REGIONAL DEVELOPMENT POLICY
}

\section{Palinchak M. M.}

\section{INTRODUCTION}

EU regional policy has been characterized by a history describing a period of over 50 years. Its essential filling has been transformed within this period. Initially, it was shaped around the implementation of infrastructure projects, and later became deeply meaningful in the form of the "Europe of the Regions" concept, which is the result of regional interactions deepening and complicating relations in the global competitive environment. Nowadays the importance of the "Europe of the Regions" is growing in the context of EU regional policy relative to subnational entities and in the geopolitical dimension as a whole.

In scientific literature much attention has been focused on the region as a structural unit of the integration union. It is often seen as a link between national member states with the EU as a coherent supranational entity. There are many representatives of foreign scientific environment and scientists-economists from Ukraine among well-known researchers, studying the EU regions and the policies of the countries of regional character, e.g. EU regional policy has been considered by Y. Wannop, Z. Gerasymchuk, M. Dolishniy, M. McGinnis, D. Palma, M. Porter, G. Richardson, M. Storper, R. Walker, S. Hardy, M. Hart, V. Chuzhikov and others. However, as globalization and integration processes are becoming stronger in the global economic environment, new aspects of regional development and interaction are constantly emerging. The European Union is forced to monitor the necessary changes in regional policy constantly in order to be able to respond effectively to the challenges of the global economic environment and to be a fully-fledged strong player. 


\section{Transformation of Regional Policy in the EU}

There are various interpretations of the concept "region" in scientific literature, particularly in regional studies, and namely:

1. The part of the country (region, district) that differs from the others in certain ways: natural-climatic, economic-geographical and others, which are considered in combination with the peculiarities of the national composition of the population.

2. Spatially organized form of population life activity, including the spheres of residence, professional and labor activity, managed from a single center and united by numerous links (industrial, political, socioeconomic, cultural, ethnic, etc.) on the basis of self-management and full realization of their rights as a subject of socio-political life.

3. A large taxonomic unit of the production-territorial structure of the country and a form of organization of production and social life of the population, which is characterized by geoeconomic, geopolitical, production-economic, cultural-ethnic, dynamic characteristics.

4. Territory within the administrative boundaries of a particular country, characterized by the complexity, integrity, specialization and controllability, that is, the presence of political and administrative governing bodies ${ }^{1}$.

On the basis of such approaches, the characteristic features of the region have been distinguished. The most important of them are:

- the unity and integrity of the region;

- community and unity of the economy;

- comprehensive economy;

- availability of population possessing appropriate education, qualification and traditional production skills;

- entering the market and using the actual amount of labor, land, capital;

- specialization;

${ }^{1}$ Бутов В.И., Игнатов В.Г., Кетова Н.П. Основы региональной экономикию. Москва, Ростов-на-Дону : Мар, 2000. 448 с. 
- controllability that implies the functioning of political and administrative governing bodies ${ }^{2}$.

Most often the "region" is considered within the national boundaries, although the variety of ways of its interpreting goes beyond the state level. That is, the region may be a state as a whole, and several states being close in character, criteria of analysis or practice.

The concept of regional policy is a complex and multidimensional concept. The regional policy of the European Union (further - EU), also referred as Cohesion Policy, is a policy with the stated aim of improving the economic well-being of regions in the EU and also to avoid regional disparities ${ }^{3}$.

It is a policy aimed at managing economic, political and social development within the region in order to achieve the set goals complemented simultaneously with the crystallization process along with the dynamic changes of the EU development as a separate integration group within the world economy. The achievement of the goals is partly due to the interaction of the regions with each other.

O. Polikarpova analyzed the transformation of the EU Regional Policy objectives within the period from 2000 to 2020 (see Table 1).

Table 1 demonstrates that for three periods the main long-term goal is a policy of disparities balancing in the development of EU regions, along with the quality of domestic economic development improving in the first period, consolidation processes - in the second, and enhancing the EU's potential as a subject of international economic relations - in the third period.

The focus of the European Union on regional development has been also changed. Transformation of regional development policy is shown on Figure 1.

${ }^{2}$ Регіональна політика Європейського Союзу : підручник / за ред. В. Чужикова. Київ : КНЕУ, 2016. 495 с.

${ }^{3}$ Regional policy of the European Union. URL: https://en.wikipedia.org/wiki/ Regional_policy_of_the_European_Union 
Transformation of EU regional policy objectives in 2000-2020 4

\begin{tabular}{|l|l|l|}
\hline \multicolumn{3}{|c|}{ Regional policy objectives } \\
\hline \multicolumn{1}{|c|}{ 2000-2006 } & \multicolumn{1}{|c|}{$\mathbf{2 0 0 7 - 2 0 1 3}$} & \multicolumn{1}{c|}{$\mathbf{2 0 1 4 - 2 0 2 0}$} \\
\hline $\begin{array}{l}\text { Promoting of } \\
\text { development and } \\
\text { structural regulation of } \\
\text { lagging regions }\end{array}$ & $\begin{array}{l}\text { Convergence and } \\
\text { competitiveness }\end{array}$ & $\begin{array}{l}\text { Increasing economic } \\
\text { growth and investment, } \\
\text { poverty reduction }\end{array}$ \\
\hline $\begin{array}{l}\text { Supporting the } \\
\text { economic and social } \\
\text { transformation of areas } \\
\text { facing structural } \\
\text { difficulties }\end{array}$ & $\begin{array}{l}\text { Regional } \\
\text { competitiveness and } \\
\text { employment at } \\
\text { regional and national } \\
\text { level }\end{array}$ & $\begin{array}{l}\text { Research and } \\
\text { innovation, } \\
\text { development of } \\
\text { information and } \\
\text { communication } \\
\text { technologies }\end{array}$ \\
\hline $\begin{array}{l}\text { Support of adaptation } \\
\text { and modernization } \\
\text { policies, training and } \\
\text { employment }\end{array}$ & $\begin{array}{l}\text { European territorial } \\
\text { cooperation }\end{array}$ & $\begin{array}{l}\text { Resources and } \\
\text { environment } \\
\text { protection, as well as } \\
\text { strengthening } \\
\text { institutional capacity }\end{array}$ \\
\hline
\end{tabular}

Regional policy is an EU tool for local investment. It is directed to boost the economic growth and jobs and improve the life quality. Thanks to this active form of EU solidarity, people in less developed regions can seize the opportunities raised by the largest market in the world.

EU regional policy works to make a difference in five key areas:

- investing in people by supporting access to employment, education and social inclusion opportunities;

- supporting the development of small and medium size businesses;

- strengthening research and innovation through investment and research-related jobs;

- improving the environment through major investment projects;

${ }^{4}$ Полікарпова О. Регіональна політика ЄС: практичний досвід для України. Вісник THEУ. 2015. № 3. C. 101-110. 


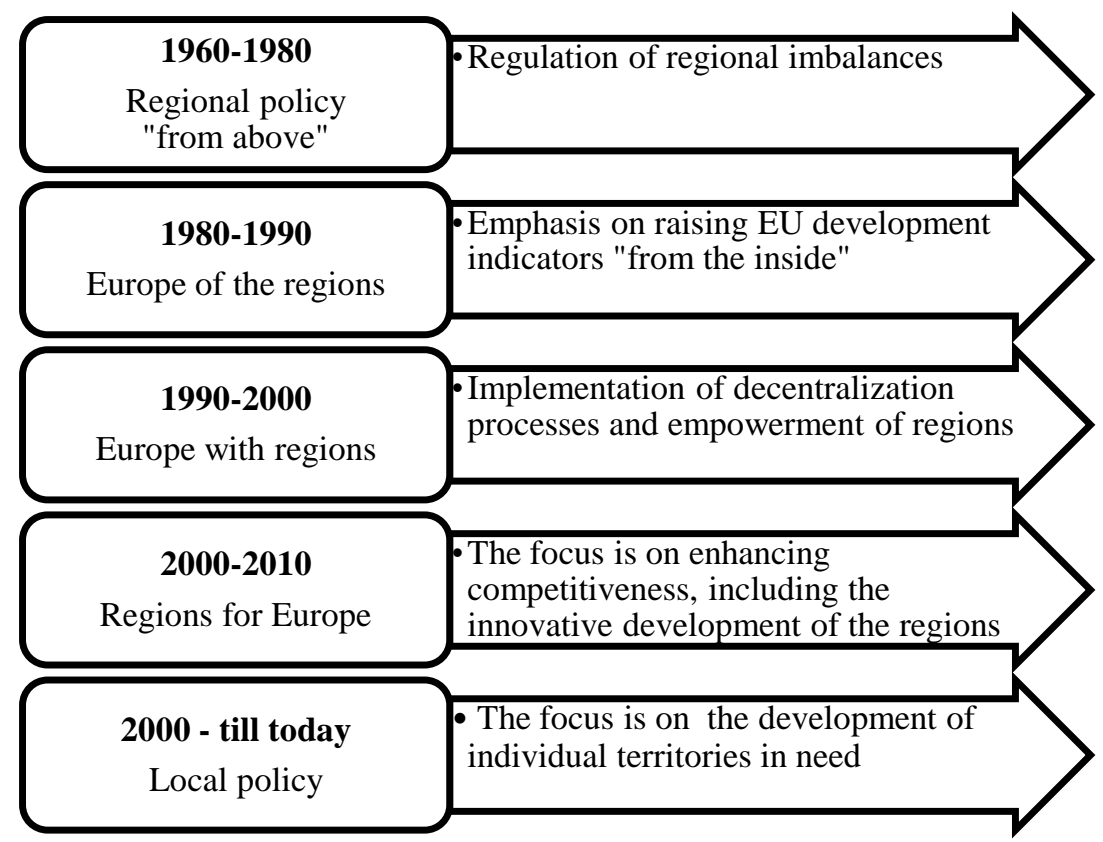

Figure 1. Transformation of regional policy in the EU since $1960^{5}$

- modernising transport and energy production to fight against climate change, with a focus on renewable energy and innovative transport infrastructure ${ }^{6}$.

Regional policy is not just an economic policy, it covers, as mentioned above, social issues, namely employment, education and skills, which is particularly important. The development of small and medium-sized enterprises, innovative issues and supporting of various types of research are of great importance. These issues are complemented by environmental protection issues that at first glance appear to be separated from regional development. It is gratifying that the European

${ }^{5}$ Innovative strategies of territorial development of V4: Experience for Ukraine / Y. Savelyev, I. Lishchynskyy, M. Lyzun, K. Borsekova, M. Sokołowicz, K. Vitališova, Y. Kurylyak. Ternopil: Terno-graf, 2016. 216 p.

${ }^{6}$ Regional policy. Regional investment and solidarity. URL: Regional Policy https://europa.eu/european-union/topics/regional-policy_en 
Union is building its policy in an integrated way, taking into account the fundamental aspects of sustainable development policy.

More than one third of the EU's budget is devoted to this policy, which aims to remove economic, social and territorial disparities across the EU, restructure declining industrial areas and diversify rural areas which have declining agriculture. In doing so, EU regional policy is geared towards making regions more competitive, fostering economic growth and creating new jobs ${ }^{7}$.

It is important to realize that the latest EU enlargement has resulted in a $10 \%$ increase in production, a $22 \%$ increase in population, $5 \%$ - in agriculture and $30 \%$ - in the number of unemployed. The population of regions with GDP per capita less than a third of the EU average has risen to 62 million (20\% of the EU population) ${ }^{8}$. Such indicators further actualize the alignment of intra-regional EU asymmetries.In general, disproportionality is reflected in the indicators of living standards and economic development, which have only deepened with each phase of expansion ${ }^{8}$. On the one hand, the EU has expanded its potential and scope in the world economy, while on the other it was complemented by some economically backward regions and countries where domestic conflicts took place. Regions with varying duration of economic policy making and formation, specialization specificities, ethnic differences, which often result in civilizational clashes or interpenetrations, have begun to be clearly observed.

Currently, according to GDP per capita indicator (calculated on the PPP), EU countries are quantitatively divided into the following groups:

1. 10 relatively affluent countries in Western and Northern Europe (which include Ireland) with GDP per capita of more than $110 \%$ of the EU average;

7 Regional policy of the European Union. URL: https://en.wikipedia.org/wiki/ Regional_policy_of_the_European_Union

8 Поліщук Л.С. Регіональні симетрії в ЄС та нові інструменти політики вирівнювання. Актуальні проблеми міжнародних відносин. 2015. Вип. 126 (част. II). C. 116-124. 
2. Italy and Germany, where the GDP per capita is higher than the European average, in highly developed regions and "problem areas" (respectively in the south and east);

3. 7 small and medium-sized Mediterranean countries (including Spain and Slovenia) where GDP per capita is below the European average, but the gap does not exceed $30 \%$;

4. 9 Eastern European countries where GDP per capita has fluctuated from 30 to $70 \%$ of the EU average in recent years.

\section{Structural Funds as Mechanisms of Regional Policy Implementation}

Asymmetry overcoming in the EU requires the costs of the Structural Funds and the development of equalization mechanisms ${ }^{8}$.

Within the period from 2014 to 2020 the European regional policy has been closely connected with the activity of three funds: the European Regional Development Fund (ERDF), The European Social Fund (ESF) and the Cohesion Fund (CF). Their activities are often compared or viewed within the context of other funds, such as the European Agricultural Fund for Rural Development (EAFRD), the European Maritime and Fisheries Fund (EMFF) and the Youth Employment Initiative (YEI). The percentage of allocation of these funds' financing processes within the period from 2014 to 2020 is shown at Figure 2.

The largest amounts of funding are provided by the European Regional Development Fund. The European Agricultural Fund for Rural Development ranks second in terms of funds. They are immediately followed by the European Social Fund and the Cohesion Fund. Together, these 4 funds account for $97.2 \%$ of the funds. In fact, they are the main financial instruments for implementing EU regional development policy.

It is important to examine in greater detail the competence of each fund in the field of regional policy implementation.

The aim of the European Regional Development Fund's activity is to reduce the economic and social imbalances between the EU regions. The central part is occupied by the attention to research and innovation, small and medium entrepreneurship, digital and the low-carbon economy. 
Combined approach of the European Regional Development Fund to financing these spheres in different types of regions is worth our attention. So, the amount of resources allocated by the ERDF depends on the level of the region development. The ERDF resources allocated to these priorities will depend on the category of region. At least $80 \%$ of funds must focus on at least two of these priorities in more developed regions. In transition regions, this index is $60 \%$ of the funds and $50 \%-$ in less developed regions.

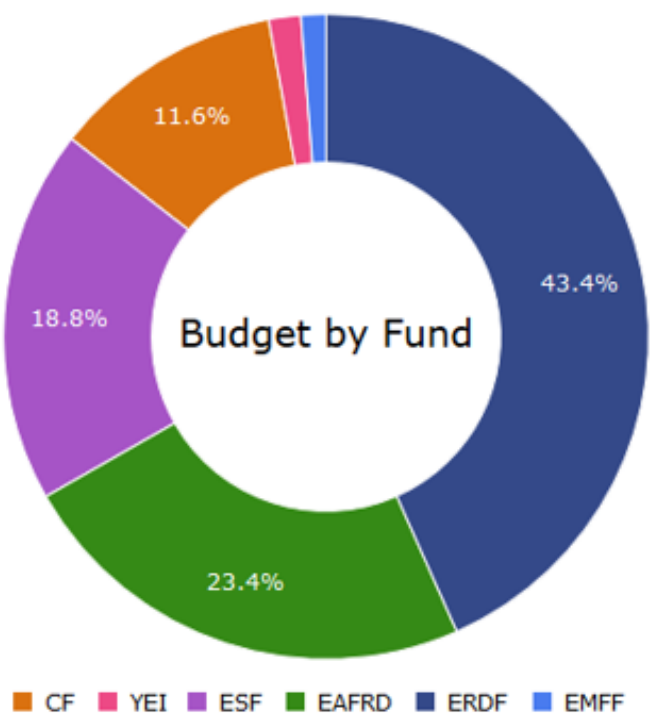

Figure 2. Allocation of funds of EU Structural Funds for the period 2014-2020, $\%^{9}$

A differentiated approach is also maintained for financing lowcarbon economy projects. $20 \%$ of the allocated funds are sent to the developed regions, $15 \%$ - to the transition regions and $12 \%$ - to the less

\footnotetext{
9 European Structural and Investment Funds. EU Overview. URL: https://cohesiondata.ec.europa.eu/overview\#
} 
developed ones ${ }^{10}$. It is gratifying to note that a feature of EU regional policy is that the least developed regions, although less involved in the priority areas of the EU economy, are not deprived of them.

One of the important goals of the European Regional Development Fund is to reduce the importance of borders within Europe. Reducing the importance of borders is important both between and within EU countries. The ERDF can achieve this goal by activating regional cooperation, and namely: cross-border, transnational and interregional cooperation. This trend can be developed in the form of cross-border and transnational as well as interregional cooperation.

The European Social Fund is busy with the poverty problem and its solution. Much attention has been devoted to the education issue. This fund is oriented to help people who are in the risk group according to the poverty as a result of education, training and employment issues increasing ${ }^{11}$.

During the specified period from 2014 to 2020 the activities of the European Regional Development Fund and the European Social Fund are oriented differently to different regions of the European Union. At figure 3 the eligibility of the funds is marked by the color.

Figure 3 shows that most of these funds are directed to the least developed regions where GDP per capita is less than the EU-27 and transitional economies, where GDP per capita is more than $75 \%$ and less than $90 \%$ of the EU - 27 average. It is important to note that, to a lesser extent, attention is also paid to developed regions where GDP per capita is more than $90 \%$ of the EU - 27 average. That is, Structural Funds contribute to both narrowing the gap between levels of regional development and maintaining high levels of development. In general, it influences the unity and mutual understanding of the regions and the

${ }^{10}$ European Regional Development Fund. The ERDF aims to strengthen economic and social cohesion in the European Union by correcting imbalances between its regions. URL: https://ec.europa.eu/regional_policy/en/funding/erdf/

${ }^{11}$ A Europe of the regions - What is EU Regional Policy? URL: http://hum.port.ac.uk/ europeanstudieshub/learning/module-3-governance-in-a-multi-level-europe/a-europe-of-theregions-what-is-eu-regional-policy/ 
strength of such an integration structure and its position in the market. This completely dispels the myth that only the least developed countries benefit from the structural funds' financing of the regional development, while the largest financial contributions are made by the developed countries. In 2017, 11 EU countries - the richest - paid more into the EU budget than what they received back in EU funding ${ }^{12}$.

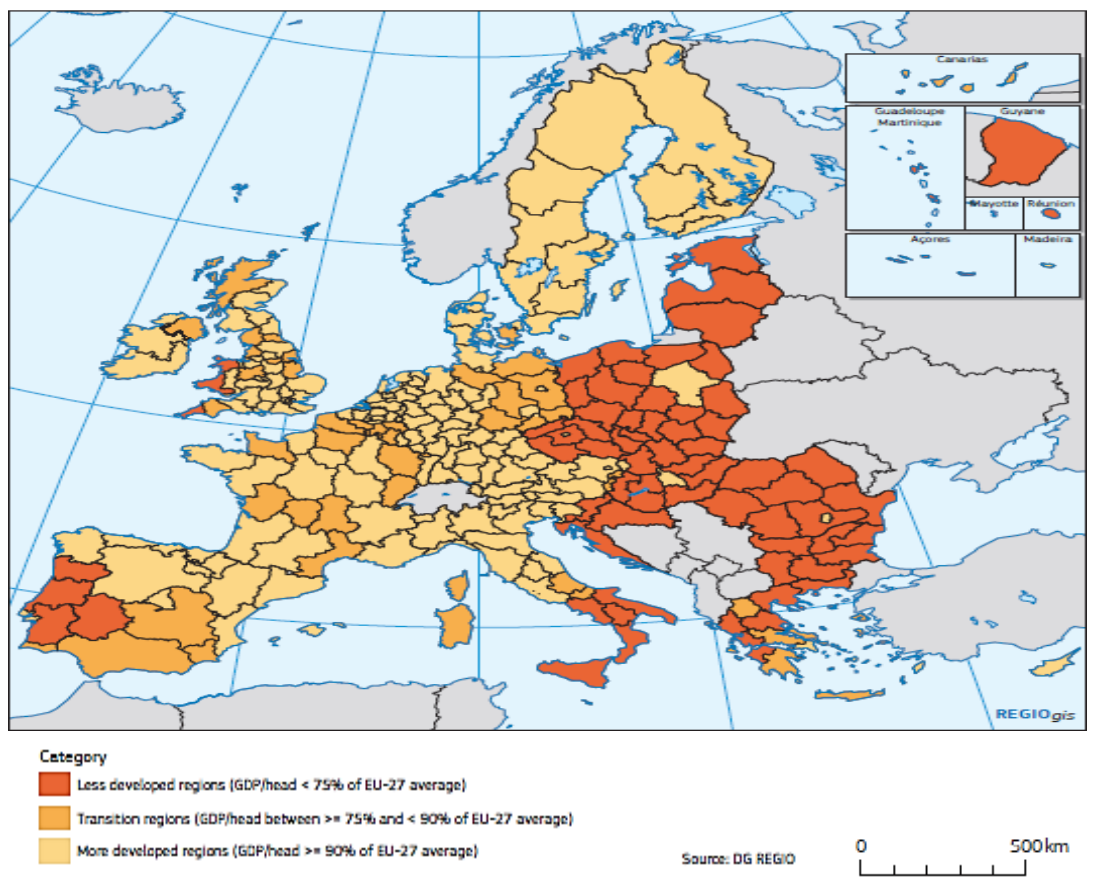

\section{Figure 3. The eligibility of the Structural Funds (ERDF and ESF) within the period from 2014 to $2020^{13}$}

${ }^{12} 10$ myths and facts about EU Cohesion policy URL: https://ec.europa.eu/ regional_policy/en/policy/what/myth-busting/

${ }^{13}$ My Region, my Europe, our Future. Seventh report on economic, social and territorial cohesion / L. Dijkstra, European Commission, Directorate-General for Regional and Urban Policy. Luxembourg : Publications Office of the European Union, 2017. 220 p. 
Even if these countries do not receive so much direct financial benefits, they can enjoy the opportunities created in this way throughout the European Union, namely they live in a stable economic and political environment within the EU with the appropriate level of security. The implementation of infrastructure projects also creates the appropriate conditions from which developed regions benefit and can focus on integration freedoms ensuring. This myth is also debunked by international trade, whose growth confirms the involvement of both the underdeveloped and developed EU regions.

The aim of the Cohesion Fund activity is to help the regions whose GNI/inhabitant is less than $90 \%$ of the EU average to approach towards the richer regions. Regions of this kind are: Bulgaria, Croatia, Cyprus, the Czech Republic, Estonia, Greece, Hungary, Latvia, Lithuania, Malta, Poland, Portugal, Romania, Slovakia and Slovenia.

Financial resources of the Cohesion Fund ( $€ 63.4$ billion for the 2014-2020 period) are allocated to specific areas. One of the priorities is the direction of trans-European transport networks. The European Union pays much attention to infrastructure projects in the framework of the cooperation with the Connecting Europe Facility, whose main objective is a high level of connectivity between European Union member states. Much attention is paid by the European Union to the environment and ecological issues, which are also part of the Cohesion Fund's competence. The Cohesion Fund supports projects related to energy or transport, developing rail transport, supporting intermodality, strengthening public transport etc. ${ }^{14}$

Generally, it can be noted that the investment priorities of the Cohesion Fund are all measures that contribute to the development of:

- a low-carbon economy;

- climate change adaptation, risk prevention and management;

- environmental protection/conservation;

${ }^{14}$ Cohesion Fund. URL: https://ec.europa.eu/regional_policy/en/funding/cohesion-fund/ 
- sustainable transport and removing bottlenecks ${ }^{15}$.

The European Regional Development Fund and the Cohesion Fund mainly implement the largest projects in the field of EU regional policy. 'Major Projects' are usually large-scale infrastructure projects in transport, environment and other sectors such as culture, education, energy or $\mathrm{ICT}^{16}$. More than $€ 50$ million is being allocated for their implementation. It is important to consider the degree of the largest projects implementation by EU regions (see Figure 4).

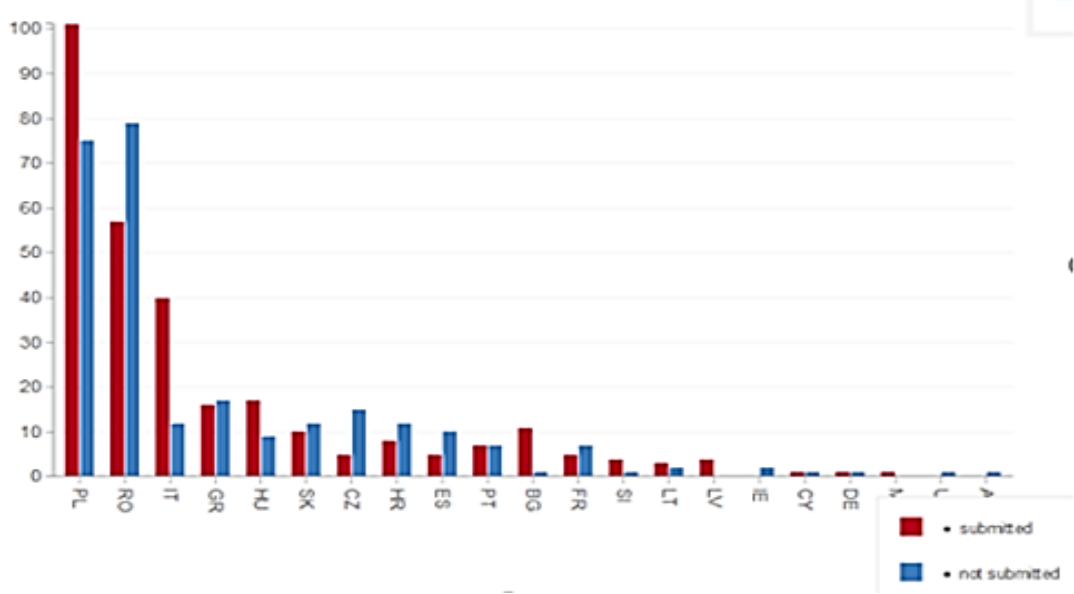

Figure 4. Participation of countries in the implementation of EU regional development projects ${ }^{16}$

Figure 4 shows that countries are involved differently in various regional policy development projects. Poland, Romania and Italy are most involved in this process. In Poland and Italy, the implemented projects prevail, in Romania - those that have not been completed. Participation of other countries is less active and there is no clear trend

15 Cohesion Fund (2014-20) URL: https://eur-lex.europa.eu/legal-content/EN/TXT/ ?uri=legissum:2602_2

${ }^{16}$ Major projects. URL: https://ec.europa.eu/regional_policy/en/projects/major/ 
for project implementation or non-implementation. It depends on various factors inherent in countries.

The total budget of the EU Structural Funds (European Regional Development Fund, Cohesion Fund, European Social Fund) for the period from 2014 to 2020 is $\$ 314.88$ billion $^{17}$. The budget is aimed at strengthening the link between cohesion policy and other common policies of the European Union, as well as developing smart strategies, job creation, tackling climate change and energy dependency, poverty reduction and social exclusion.

It is important to note that the process of regionalization is closely connected with the governance processes in the European Union. It should be clearly understood that regionalism is a reflection of the decentralization process, which entails the transfer of powers to regional authorities and is based on the principle of subsidiarity ${ }^{18}$. The cohesion policy 2014-2020 is aimed at creating strategic and institutional capacity, democratic legitimacy, strengthening administrative capacity. $67.2 \%$ of the total budget is allocated to this ${ }^{17}$.

The EU regional policy is not isolated but organically integrated into the overall economic policy of the integration group. Therefore, the threats affecting the EU economy as a whole undoubtedly transform the EU's regional policy. It should be noted that a comprehensive study of EU threats to be monitored has received little attention in scientific literature. The importance of permanent monitoring of the level of regional development is increasing in the context of transformational processes concerning regional development policy and the manifestation of economic crisis processes, which are much easier spread around the world as a result of globalization. A permanent monitoring approach would allow to systematize and develop preventative measures for the

17 Полікарпова О. Регіональна політика СС: практичний досвід для України. Вісник ТНЕУ. 2015. № 3. С. 101-110.

${ }^{18}$ European Commission. Regional policy Inforegio website: EU cohesion funding key statistics, Available budget 2014-2020. URL: http://ec.europa.eu/regional_policy/ thefunds/funding/index_en.cfm 
future. The current threats that already exist and the need of immediate resolution are identified most often.

Systematizing key threats and challenges of the EU functioning, L. Dorosh and O. Ivasechko distinguish their internal and external nature, while not forgetting their interdependence. Predominantly internal problems include the institutional crisis (the Brexit problem and making of a future vision for the EU's development) and the economic challenges that are partly influenced by the external factors. Key external threats include increased security challenges in the light of the latest hybrid conflicts in the region, the rise to power of D. Trump in the United States, terrorism as a way of destabilizing the internal situation in EU member states. Among the factors that undermine internal stability in the $\mathrm{EU}$ is, of course, the issue of the migration crisis. These factors indirectly affect the migration situation and politics, but are more concerned with social policy and the financial aspects of its implementation. Challenges of 2017 - 2018 include the possibility of launching a domino effect and increasing the tendency to withdraw from the Union of other states, the inability of its Member States to pursue a coordinated common domestic and foreign policy ${ }^{19}$.

Overcoming current threats, the institutional structures of the European Union are carrying out planned regional development projects, but are not able to pay more attention to regional aspects of the Union's economic policies. In other words, the challenges of modern EU development are hampering the effective development of EU regional policy. Without the current challenges and threats, it could be argued that European regional development policy would have developed at a much faster pace.

It is advantageous and worth considering to re-establish positive experience by developing priority directions for regional policy prospects for the next seven-year period 2021-2027. Such priority areas of

${ }^{19}$ Дорош Л., Івасечко О. Особливості функціонування та виклики розвитку ЄС у близькій перспективі (2017-2018рр.). Політичні науки. 2017. № 3. С. 19-24. 
development are being developed taking into account the strategic goals and the challenges of today.

One of the areas of investment of the European Regional Development Fund and the European Cohesion Fund will remain the sphere of innovation. The process of digitization of the EU economy, the development of industrial technologies, entrepreneurship, especially small business will continue too. Emphasis will be placed on education and the employment of youth, migration issues, climate change control and the development of a low carbon economy. Cohesion support policies will continue to be maintained for all EU regions, and further efforts will be made to reduce disparities and promote low-income and low-growth catching-up regions. A feature of the 7-year future policy is to simplify procedures for re-orienting funds to more urgent issues in the case of need and to simplify the administration of EU spending as a whole $^{20}$. The anticipated result of this approach is to make the European Union smarter, greener, carbon free, social more connected and closer to citizens ${ }^{21}$.

In the context of integration aspirations realization, Ukraine has been building its relations with the European Union for a long time. These relationships are multidimensional and are often characterized by activation or on the contrary by retardment. These are not just economic or in particular integration issues, and they have often geopolitical character.

The EU-Ukraine Association Agreement has become an instrument for bringing Ukraine and the EU closer. This Agreement is an opportunity for cooperation in the regional aspect, an opportunity for united confrontation to global challenges that are equally confronting both Ukraine and the EU.

As a result of signing the Association Agreement, it can be stated with confidence that regional cooperation between Ukraine and the EU is

${ }^{20}$ Куйбіда В. С., Федулова Л. І. Нова регіональна політика ЄС: уроки для України : аналіт.зап. Київ : НАДУ, 2019. 24 с.

${ }^{21}$ New Cohesion policy URL: https://ec.europa.eu/regional_policy/en/2021_2027/ 
not limited to the state level, but develops at the level of individual administrative-territorial units. It has been stated in the Article 446 of the Association Agreement that "the Parties shall promote mutual understanding and bilateral cooperation in the field of regional policy concerning the methods of formulation and implementation of regional policies, in particular multilevel governance and partnership, with particular emphasis on the development of backward territories and territorial co-operation, while creating communication channels and enhancing the exchange of information between national, regional and local authorities, socio-economic entities and civil society representatives" $" 22$.

The deepening of cooperation between Ukraine and the EU in the regional aspect implies active cooperation of regional and local authorities. This requires the development of a clear legislative framework that will assist Ukraine's European integration steps in the future, as well as deepening cross-border and border links between regional units, often in the form of joint programs and projects, meetings and exchanges of experience. The regional level has multidimensional directions for the development of integration processes. Such areas as transport, energy, communications networks, culture, education, tourism, health care and the coordination of emergency services are particularly effective in this regard ${ }^{23}$.

In general, the European Union's experience in the field of regional policy points to the importance of certain aspects ${ }^{24}$, in particular:

1. High importance of economic framework conditions. The success of economic development depends on ensuring of equal conditions for economic actors of different levels. Within the framework

22 Угода про Асоціацію між Україною, 3 однієї сторони, та Європейським Союзом, Свропейським співтовариством з атомної енергії і їхніми державами-членами, 3 іншої сторони. URL: http://zakon3. rada.gov.ua/laws/show/984_011

${ }^{23}$ Куриляк М.Ю. Еволюція концепції «Європи регіонів» у рамках регіональної політики ЄС. Економічний вісник Донбасу. 2018. № 2 (52). С. 60-67.

${ }^{24}$ Європейська регіональна політика: натхнення для країн, що не входять до ЄС? Застосування принципів та обмін досвідом. URL: https://ec.europa.eu/international/ external_uk 
of regional policy, it is advantageous to combine the cooperation of entities at the micro and macro levels within the framework of joint implementation of the general economic strategy.

\section{Strategies and programs should be adapted to the current} state of affairs. Prospective programs and strategies should be tailored to the needs and current challenges of the regional level. Otherwise they are doomed not to be successful.

3. The importance of the stable budgets and consistent programming. The advantage of the European Union is the development of a seven-year budgetary strategy that allows the planning and implementation of long-term investment into regional development and policy. This approach allows a more careful planning and adjustment of expenditures in program implementation and budget expenditures.

4. The need for international cooperation. EU experience shows that the implementation and promotion of cross-border, transnational and interregional cooperation, which are important elements of regional policy, contribute to the development of constructive interaction between regions within and outside the neighboring countries. This in turn gives benefits not only in the economic and political spheres, but also in the social, cultural, spiritual and others.

5. Economics of agglomerations and urbanization. It is also an important component of European regional development policy. Although the region of Europe is a central focus of economic policy, particular attention is paid to the development of large cities as centers of innovative development and key drivers of economic growth.

6. The role of small and medium-sized cities and local centers. In the context of regional policy, the EU pays much attention to the polycentric development, where identical attention is given to small and medium-sized cities alongside to large cities. They provide connectivity with major cities and the dissemination of economic developments that have passed their lifecycle in major cities and continue them in downtowns with lower levels of urbanization. The EU is spending a lot 
of effort to develop rural areas and prevent significant depopulation processes, understanding all the threats that may be posed.

7. Local employment and capacity building initiatives. First and foremost such initiatives are connected with the development of the backward regions where the poverty issue is particularly actual. Overcoming the imbalances of regional territorial development implies an increase in the level of employment and, accordingly, the well-being of citizens living in these regions, and in general the level of their economic development, which lays the foundation for their future development, taking into account the challenges of today.

8. Strong institutional support. In order to achieve the successful implementation of regional initiatives, the institutional mechanism should function coherently and be well coordinated. The institutional mechanism includes both the institutions directly or indirectly involved in the implementation of EU regional policy, and the links between them, the activities of which are aimed at achieving the set of goals of regional development and securing the interests of actors of different levels and fields of activity.

9. Multilevel management. This type of management includes vertical and horizontal elements that activate integration processes.

Within the vertical management system, various levels of European, national, regional and local governments are being promoted through a plan and program development system that has developed over the years to provide information sharing and one-way traffic for local benefits. Within the horizontal management system of the company, social groups and civic organizations are actively involved in the process and activities of governing bodies ${ }^{24}$.

\section{CONCLUSIONS}

The EU's regional policy has undergone significant transformations during its existence, evolving from a policy of a united Europe to create a favorable economic environment to a policy of united potential of a strong player in the international arena. The strategic goals of EU regional policy were to ensure the economic 
growth of the community as a single integration group and a correspondingly high level of citizens' well-being. The overarching goals remained unchanged, while the interim goals that ensured the implementation of the chosen strategy were adjusted according to the current situation and the global economic environment. The European Union is making continuous efforts to minimize the disproportionate and asymmetric development of EU regions, facilitating the management and regulation of individual processes. The main tools are the EU Structural Funds financial mechanisms that implement regional development programs differing in several levels of development. It is important to take into account the inconsistency of individual myths about the inefficiency of regional policy and the overriding focus on underdeveloped regions. Indirect benefits also come from developed regions, which are more involved in the financing and implementation of EU regional policy. Certain regional policy approaches may be exemplary for countries, including Ukraine, for the interaction of regions in order to strengthen the integrity and economic potential of the subject of international relations.

\section{SUMMARY}

The main aspects of the EU regional policy transformation have been considered by the author. The essence and main characteristics of the region have been analyzed. Today the region is of great importance in the global economic environment, so much attention has been paid to regional policy. The transformation of the goals of EU regional policy during 2000-2020 has been analyzed by the author. The Structural Funds are the financial mechanism for the implementation of EU regional policy. They help to reduce imbalances in the levels of development of the regions, to support the high level of development of the rich ones, which affects the unity and cooperation of the regions. The EU regional policy is an integral part of the overall economic policy of the integration grouping and is influenced by the threats of the EU economy as a whole. The importance of permanent monitoring the level of regional development in the context of transformation processes and the 
manifestation of economic crisis phenomena in the era of globalization has been emphasized by the author. That will allow timely response to threats and preventive measures working-out. Some elements of the EU regional policy experience can be applied to regional development policy in Ukraine.

\section{REFERENCES}

1. Бутов В.И., Игнатов В.Г., Кетова Н.П. Основы региональной экономики. Москва, Ростов-на-Дону : Мар, 2000. $448 \mathrm{c}$.

2. Регіональна політика Європейського Союзу : підручник / за ред. В. Чужикова. Київ : КНЕУ, 2016. 495 с.

3. Regional policy of the European Union. URL: https://en.wikipedia.org/wiki/Regional_policy_of_the_European_Union

4. Полікарпова О. Регіональна політика $\mathrm{CC}$ : практичний досвід для України. Вісник ТНЕУ. 2015. № 3. С. 101-110.

5. Innovative strategies of territorial development of V4: Experience for Ukraine / Y. Savelyev, I. Lishchynskyy, M. Lyzun, K. Borsekova, M. Sokołowicz, K. Vitališova, Y. Kurylyak. Ternopil: Terno-graf, 2016. 216 p.

6. Regional policy. Regional investment and solidarity. URL: Regional Policy https://europa.eu/european-union/topics/regionalpolicy_en

7. Regional policy of the European Union. URL: https://en.wikipedia.org/wiki/Regional_policy_of_the_European_Union

8. Поліщук Л.С. Регіональні симетрії в СС та нові інструменти політики вирівнювання. Актуальні проблеми міжнародних відносин. 2015. Вип. 126 (част II). С. 116-124.

9. European Structural and Investment Funds. EU Overview. URL: https://cohesiondata.ec.europa.eu/overview\#

10. European Regional Development Fund. The ERDF aims to strengthen economic and social cohesion in the European Union by correcting imbalances between its regions. URL: https://ec.europa.eu/ regional_policy/en/funding/erdf/ 
11. A Europe of the regions - What is EU Regional Policy? URL: $\quad$ http://hum.port.ac.uk/europeanstudieshub/learning/module-3governance-in-a-multi-level-europe/a-europe-of-the-regions-what-is-euregional-policy/

12. My Region, my Europe, our Future. Seventh report on economic, social and territorial cohesion / L. Dijkstra, European Commission, Directorate-General for Regional and Urban Policy. Luxembourg : Publications Office of the European Union, 2017. 220 p.

13. 10 myths and facts about EU Cohesion policy URL: https://ec.europa.eu/regional_policy/en/policy/what/myth-busting/

14. Cohesion Fund. URL: https://ec.europa.eu/regional_policy/ en/funding/cohesion-fund/

15. Cohesion Fund (2014-20) URL: https://eur-lex.europa.eu/ legal-content/EN/TXT/?uri=legissum:2602_2

16. Major projects. URL: https://ec.europa.eu/regional_policy/ en/projects/major/

17. Полікарпова О. Регіональна політика $\mathrm{CC}$ : практичний досвід для України. Вісник ТНЕУ. 2015. № 3. С. 101-110.

18. European Commission. Regional policy Inforegio website: EU cohesion funding - key statistics, Available budget 2014-2020. URL: http://ec.europa.eu/regional_policy/thefunds/funding/index_en.cfm

19. Дорош Л., Івасечко О. Особливості функціонування та виклики розвитку СС у близькій перспективі (2017-2018рp.). Політичні науки. 2017. № 3. С. 19-24.

20. Куйбіда В. С., Федулова Л. І. Нова регіональна політика ЄС: уроки для України : аналіт.зап. Київ : НАДУ, 2019. 24 с.

21. New Cohesion policy URL: https://ec.europa.eu/ regional_policy/en/2021_2027/

22. Угода про Асоціацію між Україною, з однієї сторони, та Свропейським Союзом, Свропейським співтовариством 3 атомної енергії i їхніми державами-членами, 3 іншої сторони. URL: http://zakon3. rada.gov.ua/laws/show/ 984_011 
23. Куриляк М.Ю. Еволюція концепції «Свропи регіонів»у рамках регіональної політики ЄС. Економічний вісник Донбасу. 2018. № 2 (52). С. 60-67.

24. Європейська регіональна політика: натхнення для країн, що не входять до $Є С$ ? Застосування принципів та обмін досвідом. URL: https://ec.europa.eu/international/external_uk

\section{Information about the author:} Palinchak M. M., Doctor of Political Science, Professor, Dean of the Faculty of International Economic Relations, Uzhhorod National University 14, Universytetska str, Uzhhorod, 88000, Ukraine 